Ekonomis: Journal of Economics and Business, 5(1), Maret 2021, 73-77

Publisher: Lembaga Penelitian dan Pengabdian kepada Masyarakat Universitas Batanghari Jambi

Address: Jl. Slamet Ryadi, Broni-Jambi Kodepos: 36122

Website: http://ekonomis.unbari.ac.id, email: ekonomis.unbari@gmail.com

ISSN 2597-8829 (Online), DOI 10.33087/ekonomis.v5i1.194

\title{
Dampak Covid-19 terhadap Fluktuasi Harga Saham dan Volume Transaksi Saham pada Perusahaan Subsektor Telekomunikasi Yang Terdaftar di Bursa Efek Indonesia
}

\author{
Listya Devi Junaidi", Lukman Hakim Siregar, Malesa Anan \\ Universitas Dharmawangsa Medan \\ Jln. KL Yos Sudarso No. 224 Medan \\ *Correspondence email: listyadevi@dharmawangsa.ac.id
}

\begin{abstract}
Abstrak. Dampak tersebarnya wabah Covid-19 tidak hanya merugikan kesehatan manusia, namun juga merugikan sisi perekonomian negara baik di dalam negeri maupun mancanegara. Pasca diumumkan masuknya wabah ini ke Indonesia pada tanggal 02 Maret 2020, pemerintah berupaya keras untuk menekan penyebaran virus ini, yaitu melalui social distancing, working from home (WFH) dan kegiatan belajar mengajar dari rumah. Kegiatan tersebut mengharuskan masyarakat untuk selalu berhubungan dengan media elektonik seperti laptop, smartphone dsb. Namun, keadaan tersebut telah menguntungkan perusahaan subsector telekomunikasi dimana kebutuhan layanan internet semakin meningkat. Riset ini didesign untuk menganalisis bagaimana komparasi harga saham dan volume transaksi saham pada perusahaan subsektor Telekomunikasi sebelum dan sesudah pengumuman penyebaran Covid-19 di Indonesia. Riset ini memakai normality test dan uji hipotesis Paired Sample T-Test. Adapun temuan riset membuktikan bahwa Covid-19 mempunyai imbas yang cukup signifikan terhadap nilai harga saham dan volume transaksi saham pada subsektor telekomunikasi dimana nilai harga saham dan volume transaksi harga saham yang sebelumnya mengalami peningkatan namun justru menjadi menurun.
\end{abstract}

Kata kunci: Covid-19; Harga Saham; Volume Transaksi Saham

\begin{abstract}
The impact of the spread of the COVID-19 outbreak is not only detrimental to human health but also detrimental to the country's economy both domestically and abroad. After the announcement of the entry of this outbreak to Indonesia on March 2, 2020, the government tried to make various efforts to reduce the spread of this virus, namely by conducting social distancing, work from home (WFH) and, teaching and learning activities from home. This activity requires people to always be in touch with electronic media such as laptops, smartphones, etc. However, this situation has benefited subsector Telecommunication companies where the need for internet services is increasing. This study aims to determine how the comparison of stock prices and share transaction volume in telecommunication sub-sector companies before and after the announcement of the spread of COVID-19 in Indonesia. This research uses A normality test and hypothesis test Paired Sample T-Test. The results of this study indicate that COVID-19 has a significant impact on the value of stock prices and the volume of stock transactions in the telecommunications sub-sector where the value of stock prices and the volume of stock price transactions that had previously increased but decreased.
\end{abstract}

Keywords : COVID-19; Stock Prices; Volume of Stock Price

\section{PENDAHULUAN}

Dampak tersebarnya wabah Covid-19 tidak hanya merugikan kesehatan manusia, namun juga merugikan sisi perekonomian negara baik di dalam negeri maupun mancanegara. Pasca diumumkan masuknya wabah ini ke Indonesia pada tanggal 02 Maret 2020, Pemerintah berupaya keras untuk meminimalisir penyebaran virus ini. Adapun berbagai stimulus yang dilakukan pemerintah, apalagi Pemerintah mengharuskan segala kelompok masyarakat untuk menjalankan jaga jarak (social distancing), bekerja dari rumah (Work From Home) dan kegiatan belajar mengajar dari rumah. Upaya pencegahan melalui social distancing, membuat semua masyarakat harus berdiam diri dirumah untuk menjaga jarak atau saat ini diberi julukan "Stay at Home". Dengan diwajibkannya masyarakat melakukan social distancing dan berdiam dirumah membuat beberapa sektor industri melemah bahkan hingga gulung tikar. Secara keseluruhan, dari data Kementerian Perindustrian yang di dapatkan setidaknya lebih kurang $60 \%$ industri terkena dampak virus Corona sedangkan lebih urang $40 \%$ sisanya terkena dampak sedang bahkan justru menerima permintaan yang cukup tinggi. Adapun sektor industri yang mengalami penurunan yaitu industri elektronik, logam, peralatan listrik, kabel, kaca, semen, keramik, dan peralatan alat berat, alat komunikasi, mesin, karet, tekstil, otomotif, pesawat terbang,kereta api, dan lain sebagainya (finance.detik.com).

Selama penyebaran virus Covid-19, tuntutan rakyat terhadap digital life style melalui akses data melalui internet juga meningkatkan kinerja penerbit telekomunikasi. Selama pandemi Covid-19, trafik data PT Telkomsel Tbk (TLKM) juga meningkat sebesar 22,8\%. Tingkat pemanfaatan teknologi berbasis pertemuan virtual dan layanan streaming video meningkat masing-masing sebesar $75 \%$ serta 13,8\%. Menurut Direktur Utama PT Setyanto. 
Penggunaan layanan data Telkom Indonesia sebagai persentase dari wilayah bisnis yang mengalami peningkatan berada di Sumatera Selatan, Sumatera Utara dan Jawa Barat dengan peningkatan maksimal sekitar 35\% dibandingkan hari biasa (cnbcindonesia.com). Pemakaian layanan pada aplikasi belajar online, aplikasi pendukung kerja dari rumah, dan layanan video-conference yang kini mengalami peningkatan yang sangat signifikan. Emiten menyatakan pemakai aktif layanan Zoom telah sampai 200 juta pengguna, atau melonjak sebanyak 20 kali lipat selama 3 bulan mulai akhir tahun 2019. Selanjutnya, layanan media sosial (medsos) dan layanan nonton video streaming telah banyak dimanfaatkan oleh masyarakat menjadi opsi hiburan di masa pandemi. Peningkatan penggunaan layanan game online ditaksir mencapai $61 \%$. Melonjaknya pemanfaatan game bukan semata-mata berlaku di Negara Indonesia, namun di berbagai negara dampak seluruh negara menjalankan lockdown. (Investor.id). Selanjutnya maka akan dilaksanakan riset tentang akibat pandemi covid-19 terhadap emiten jasa subsektor telekomunikasi yang terdaftar di BEI. Pada penelitian ini, peneliti memakai data harga saham dan volume transaksi saham sebelum dan setelah diumumkannya kasus pertama virus corona di Indonesia.

\section{Harga Saham}

Harga saham di pasar modal akan selalu berubah sesuai dengan kondisi pasar. Kondisi ekonomi dan politik yang tidak stabil merupakan aspek yang mengakibatkan harga saham serta kenaikan serta penurunan yang tidak disangka dalam suku bunga dan nilai tukar. Harga saham bisa dipakai menjadi salah satu parameter kinerja emiten. Harga saham merupakan nilai sekarang dari arus kas yang akan diterima pemegang saham di masa yang akan datang (Anoraga, 2006). Berlandaskan pada fungsinya nilai saham dapat terbagi tiga yaitu (Widiatmojo, 2009): (1) Par Value (Harga Nominal) adalah nilai yang melekat pada saham yang relevan untuk tujuan akuntansi; (2) Base Price (Harga Dasar), merupakan harga pembukaan atau harga awal saham sebelum beredarnya saham dibursa, dan harga tersebut akan berubah sesuai dengan penambahan jumlah saham yang beredar; (3) IPO (Initial Public Offering) merupakan nilai pada saat pertama kali saham itu dilepas ke bursa, namun nilai tersebut akan terus meningkat dipengaruhi oleh perilaku emiten seperti adanya stock split, waran, right issue dll; dan (4) Market Price (Harga Pasar), pasar biasanya terjadi setelah adanya penawaran dan permintaan saham di bursa. Harga pasar tersebut nantinya akan di tetapkan oleh nilai penjualan dan penawaran terakhir.

Penjelasan tersebut, diperoleh bahwa harga saham yang terbentuk di pasar modal sangat bergantung pada kemampuan penawaran dan permintaan. Jika penerbitan saham besar, harga saham akan naik dan sebaliknya.

\section{Volume Harga Saham}

Volume transaksi saham yaitu besaran saham yang diperdagangkan atas waktu terbatas. Tingkat volume transaksi saham memperlihatkan sebagaimana banyak keinginan investor dalam menjalankan bisnis baik membeli maupun menjual saham suatu perusahaan. Tingkat volume transaksi yang melonjak, bukan berati memperlihatkan harga saham yang meningkat pula. Tingkat volume transaksi ini dapat berubah disebabkan terdapat hal-hal kejadian di internal perusahaan maupun kejadian lain di eksternal perusahaan (Nurmasari, 2020).

\section{METODE}

Dalam riset ini data yang dipakai adalah data sekunder, yaitu data nilai saham dan volume perdagangan saham dari Perusahaan jasa subsector telekomunikasi yang diambil dari internet. Data yang digunakan yaitu data harian harga saham dan volume transaksi 1 bulan sebelum serta 1 bulan setelah pemberitaan pertama penyebaran covid-19 pada 2 Maret 2020. Riset ini memakai data yang didapatkan melalui website IDX. Harga saham yang dipakai yaitu harga ketika closing price. Selanjutnya, data volume transaksi diambil melalui volume transaksi saham harian seluruh perusahaan jasa subsector telekomunikasi yang terdaftar di BEI. Metode analisis data adalah metode analisis data melalui cara mendeskripsikan. Metode yang dilakukan dalam penelitian ini yaitu membandingkan harga saham dan volume transaksi saham sebelum dan sesudah pemberitaan penyebaran covid-19 di indonesia untuk petama kali. Berikut adalah gambar alur pengujian paired sample t-test.

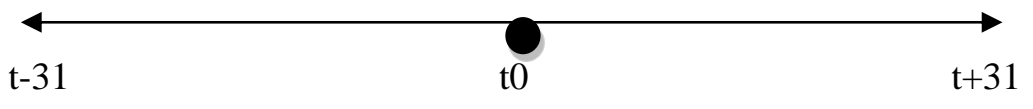

\section{Pengumuman \\ Nasional Covid-19}

Gambar 1

Alur pengujian perbandingan harga saham dan volume transaksi saham 
Listya Devi Junaidi, Lukman Hakim Siregar dan Malesa Anan, Dampak Covid-19 Terhadap Fluktuasi Harga Saham dan Volume Transaksi Saham pada Perusahaan Subsektor Telekomunikasi yang Terdaftar di Bursa Efek Indonesia

Analisis data dilakukan dengan dua tahapan yaitu yang pertama pengujian normalitas dan yang kedua uji perbandingan t-test. Test normalitas data diperlukan karena untuk menguji variabel lain dengan asumsi residual normal. Uji riset ini memakai uji one sample Kolmogorov Smirnov pada program SPSS. Selanjutnya Uji paired sample $\mathrm{t}$ test. Jika skala data dari dua variabel adalah kuantitatif (interval atau rasio), maka uji-t berpasangan atau uji-t berpasangan digunakan sebagai uji perbandingan atau perbedaan. Tes ini juga disebut tes $t$ berpasangan. Uji-t berpasangan adalah uji perbedaan parameter untuk dua data berpasangan. Menurut definisi ini, dapat dinyatakan secara lebih rinci bahwa tes tersebut dimaksudkan untuk digunakan pada tes yang berbeda atau tes komparatif.Ini berarti membandingkan sarana atau sarana dari dua kelompok berpasangan untuk mencari perbedaan. Memasangkan artinya sumber data berasal dari subjek yang sama. Uji-t berpasangan yaitu teknik tes hipotesis dimana data yang dipakai tidak independen. Ciri paling umum yang ditemukan dalam kasus berpasangan adalah orang (subjek) yang menerima 2 perlakuan berbeda. Untuk kelompok kontrol, karena data tidak terdistribusi normal untuk melihat rata-rata perubahan harga saham dan volume perdagangan saham sebelum dan sesudah negara mengeluarkan Covid-19 maka digunakan uji paired sample T test. Secara manual, rumus uji-t untuk sampel berpasangan adalah:

$$
\mathrm{t}=\frac{\delta}{S D \delta / \sqrt{n}}
$$

Ket: $\delta=$ mean deviasi; SD $\delta=$ Standar Deviasi dari $\delta ; \mathrm{N}=$ jumlah sampel

\section{HASIL DAN PEMBAHASAN}

Tabel 1

Statistik deskriptif Harga Saham dan Volume Transaksi Saham sebelum pemberitaan COVID-19 Nasional.

\section{Descriptive Statistics}

\begin{tabular}{lr|r|r|r|r} 
& N & Minimum & Maximum & \multicolumn{1}{c}{ Mean } & Std. Deviation \\
\hline HS SEBELUM & 186 & 50 & 3920 & 1763.11 & 1370.169 \\
\hline VT SEBELUM & 186 & 0 & 222798500 & 28097917.74 & 39415571.06 \\
\hline Valid N (listwise) & 186 & & & & \\
\hline
\end{tabular}

Sumber: data diolah, 2020

Hasil deskriptif variabel harga saham dan volume transaksi saham sebelum pemberitaan covid-19 Nasional dijelaskan sebagai berikut:

1. Mean harga saham sebelum pengumuman Covid-19 di Indonesia sebesar 1763.11 dengan standar deviasi 1370.169, nilai minimum sebesar 50dan nilai maksimum sebesar 3920.

2. Mean volume transaksi saham sebelum pengumuman Covid-19 di Indonesia sebesar 28097917.74 dengan standar deviasi 39415571.06, nilai maksimum sebesar 222798500 dan nilai minimum sebesar 0.

Tabel 2

Statistik deskriptif Harga Saham dan Volume Transaksi Saham sesudah pemberitaan COVID-19 Nasional

\section{Descriptive Statistics}

\begin{tabular}{lr|r|r|r|r} 
& N & Minimum & Maximum & \multicolumn{1}{c}{ Mean } & \multicolumn{1}{|c}{ Std. Deviation } \\
\hline HS SESUDAH & 186 & 50 & 3830 & 1300.12 & 1162.821 \\
\hline VT SESUDAH & 186 & 0 & 539135200 & 48071760.75 & 88516594.24 \\
\hline Valid N (listwise) & 186 & & & & \\
\hline
\end{tabular}

Sumber: data diolah, 2020

Hasil deskriptif variabel harga saham dan volume transaksi saham sesudah pemberitaan covid-19 Nasional dijelaskan sebagai berikut :

1. Mean harga saham sesudah pengumuman Covid-19 di Indonesia sebesar 1300.12 dengan standar deviasi 1162.821, nilai maksimum sebesar 3830 dan nilai minimum sebesar 50 .

2. Mean volume transaksi saham sebelum pengumuman Covid-19 di Indonesia sebesar 48071760.75 dengan standar deviasi 88516594.245, nilai maksimum sebesar 539135200 dan nilai minimum sebesar 0 . 
Listya Devi Junaidi, Lukman Hakim Siregar dan Malesa Anan, Dampak Covid-19 Terhadap Fluktuasi Harga Saham dan Volume Transaksi Saham pada Perusahaan Subsektor Telekomunikasi yang Terdaftar di Bursa Efek Indonesia

\section{Uji Normalitas}

Tabel 3

Hasil Uji Kolmogorov-Smirnov Harga Saham

\begin{tabular}{l|l|r}
\hline \multicolumn{2}{|l|}{} & \multicolumn{1}{c}{ Unstandardized Residual } \\
\hline $\mathrm{N}$ & Mean & .0000000 \\
\hline Normal Parameters $^{\mathrm{a}}$ & Std. Deviation & 2.21747223 \\
\hline Most Extreme Differences & Absolute & .082 \\
\cline { 2 - 3 } & Positive & .082 \\
\cline { 2 - 3 } & Negative & -.082 \\
\hline Kolmogorov-Smirnov Z & & 1.032 \\
\hline Asymp. Sig. (2-tailed) & & .237 \\
\hline
\end{tabular}

Sumber: data diolah, 2020

Tabel 4

Hasil Uji Kolmogrov-Smirnov Volume Transaksi

\begin{tabular}{l|l|r}
\hline \multicolumn{2}{l|}{} & \multicolumn{1}{c}{ Unstandardized Residual } \\
\hline $\mathrm{N}$ & Mean & .0000000 \\
\cline { 2 - 3 } & Std. Deviation & 2.30082418 \\
\hline Most Extreme Differences & Absolute & .079 \\
\cline { 2 - 3 } & Positive & .065 \\
\cline { 2 - 3 } & Negative & -.079 \\
\hline Kolmogorov-Smirnov Z & & .991 \\
\hline Asymp. Sig. (2-tailed) & .280 \\
\hline
\end{tabular}

Sumber: data diolah, 2020

Perolehan Normality test pada Tabel 3 dan 4 di atas, terlihat bahwa rata-rata data perubahan harga saham dengan nilai probabilitas $>$ taraf signifikasi $(\alpha=0.05)$ yaitu $0.237>0.05$, hasil tersebut dapat disimpulkan bahwa nilai harga saham terdistribusi normal. Selanjutnya, terlihat juga bahwa rata-rata data perubahan volume transaksi harga saham dengan nilai profitabilitas $>$ taraf signifikansi $(\alpha=0.05)$ yaitu $0.280>0.05$, hasil tersebut dapat disimpulkan bahwa nilai volume transaksi saham terdistribusi normal. Setelah data normal, maka riset ini memakai teknik parametrik. Kemudian dilaksanakan tes hipotesis secara parsial dengan menggunakan Uji Pair Sampel T-Test.

\section{Uji Pair Sample T-Test}

Tabel 5

Uji Paired Sample T-Test pada Harga Saham dan Volume Transaksi Saham

\begin{tabular}{|c|c|c|c|c|c|c|c|c|}
\hline & \multicolumn{5}{|c|}{ Paired Differences } & \multirow{3}{*}{$t$} & \multirow{3}{*}{$\mathrm{df}$} & \multirow{3}{*}{ Sig. (2-tailed) } \\
\hline & \multirow{2}{*}{ Mean } & \multirow{2}{*}{ Std. Deviation } & \multirow{2}{*}{ Std. Error Mean } & \multicolumn{2}{|c|}{$95 \%$ Confidence Interval of the Difference } & & & \\
\hline & & & & \begin{tabular}{|l|} 
Lower \\
\end{tabular} & Upper & & & \\
\hline \begin{tabular}{l|l|l} 
Pair 1 & HS SEBELUM - HS SESUDAH \\
\end{tabular} & 462.995 & 445.012 & 32.630 & 398.620 & 527.369 & 14.189 & 185 & .000 \\
\hline \begin{tabular}{l|l} 
Pair 2 & VT SEBELUM - VT SESUDAH \\
\end{tabular} & -19973843.011 & 79646490.691 & 5839964.041 & -31495332.554 & -8452353.468 & -3.420 & 185 & .001 \\
\hline
\end{tabular}

Sumber: data diolah

Tabel 5 diatas, Harga Saham memperlihatkan nilai signifansi = 0.000 (lebih kecil dari 0.05). Dari test tersebut disimpulkan bahwa secara signifikansi memiliki perbedaan secara signifikan harga saham sebelum dengan sesudah dumumkannya penyebaran covid-19 di Indonesia. Sedangkan volume transaksi saham menunjukkan nilai sig $=0.001$ (lebih kecil dari 0.05). Pengujian tersebut disimpulkan bahwa secara signifikansi memiliki perbedaan yang signifikan volume transaksi saham saat sebelum dengan setelah dumumkannya pemyebaran covid-19 secara Nasional.

1. Hasil uji normalitas memperlihatkan kalau data berdistribusi normal, dengan signifikansi sebesar $0.237>0.05$. Begitu juga dengan hasil uji kolmogrov smirnov pada nilai volume transaksi saham yang menunjukkan data berdistribusi normal dengan signifikansi sebesar $0.280>0.05$. 
Listya Devi Junaidi, Lukman Hakim Siregar dan Malesa Anan, Dampak Covid-19 Terhadap Fluktuasi Harga Saham dan Volume Transaksi Saham pada Perusahaan Subsektor Telekomunikasi yang Terdaftar di Bursa Efek Indonesia

2. Perolehan Uji Paired Sample T-Test dengan signifikansi 5\% juga memperlihatkan bahwa harga saham dan volume transaksi sebelum dan sesudah beritakannya penyebaran covid-19 Nasional mengalami perbedaan yang signifikan, dengan nilai signifikansi harga saham sebesar 0.000 dan nilai signifikansi volume transaksi saham sebesar 0.001 , artinya nilai harga saham dan volume transaksi saham semakin menurun setelah diumumkan penyebaran covid-19 di Indonesia pada tanggal 02 Maret 2020.

\section{SIMPULAN}

Setelah dilakukan pengujian, maka dapat disimpulkan sebagai berikut:

1. Pada nilai harga saham yang ditest melalui teknik Paired Sample T-Test memperlihatkan terdapat perbandingan yang signifikan pada nilai harga saham 31 hari sebelum dibandingkan dengan 31 sesudah diumumkannya penyebaran covid-19 di Indonesia, hal tersebut memperlihatkan bahwa covid-19 terdapat akibat yang cukup signifikan terhadap nilai harga saham pada subsektor telekomunikasi dimana nilai harga saham yang sebelumnya mengalami peningkatan namun justru menjadi menurun.

2. Pada nilai volume transaksi saham yang di test melalui teknik Paired Sample T-Test memperlihatkan terdapat perbandingan yang signifikan pada volume transaksi harga saham 31 hari sebelum dibandingkan dengan 31 sesudah diumumkannya penyebaran covid-19 di Indonesia, hal tersebut memperlihatkan bahwa covid-19 terdapat akibat yang cukup signifikan terhadap volume transaksi harga saham pada subsector telekomunikasi dimana volume transaksi harga saham yang sebelumnya mengalami peningkatan namun justru menjadi menurun.

\section{DAFTAR PUSTAKA}

Anoraga, Pandji dan Piji Pakarti. (2006), Pengantar Pasar Modal. Edisi Revisi, Cetakan Kelima. Semarang: Penerbit PT. Rineka Cipta..

Chan JF-W, Kok K-H, Zhu Z, Chu H, To KK-W, Yuan S, et al. (2020). Genomic characterization of the 2019 novel human-pathogenic coronavirus isolated from a patient with atypical pneumonia after visiting Wuhan. Emerg Microbes Infect. 9(1), 221-36.

Gorbalenya AE, Baker SC, Baric RS, de Groot RJ, Drosten C, Gulyaeva AA, et al. (2020). The species Severe acute respiratory syndrome-related coronavirus: classifying 2019-nCoV and naming it SARS-CoV-2. Nat Microbiol; published online March 2. DOI: 10.1038/s41564-020-0695-z..

https://finance.detik.com/industri/d-4985660/ini-industri-yang-paling-banyak-gulung-tikar-gegara-corona diakses 06 Juli 2020 pukul 23.14 WIB

https://kumparan.com/kumparanbisnis/daftar-perusahaan-yang-phk-karyawan-karena-corona-kfc-hingga-traveloka-

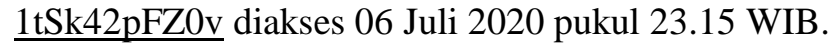

https://www.cnbcindonesia.com/market/20200611154403-17-164699/perusahaan-telekomunikasi-paling-cuan-saatpandemi-covid-19 diakses 06 juli 2020 pukul 23.17 WIB

Nurmasari Ifa. (2020). Tampak Covid-19 Terhadap Perubahan Harga Saham dan Volume Transaksi (Studi Kasus Pada PT. Ramayana Lestari Sentosa, Tbk.). Jurnal Sekuritas (Saham, Ekonomi, Keuangan dan Investasi ). 3(3), $230-236$.

Riedel S, Morse S, Mietzner T, Miller S. Jawetz, Melnick, \& Adelberg's. (2019). Medical Microbiology. 28th ed. New York: McGraw Hill Education/Medical. p.617-22.

Satria, Rendi Dan Supatmi. (2013). Reaksi Pasar Sebelum dan Sesudah Internet Financial Reporting. Jurnal Akuntansi Dan Keuangan. Fakultas Ekonomika dan Bisnis Universitas Kristen Satya Wacana. 15(2), 86-94.

Sugiyon. (2016), Metode Riset Kombinasi. Penerbit Alfabeta. Bandung.

Sutrisno.(2009). Manajemen Keuangan Teori, Konsep dan Aplikasi. Edisi Pertama, Cetakan. Ketujuh, Penerbit Ekonisia, Yogyakarta.

Zhang T, Wu Q, Zhang Z. (2020). Probable Pangolin Origin of SARSCoV-2 Associated with the COVID-19 Outbreak. Curr Biol, published online March 13. DOI: 10.1016/j.cub.2020.03.022.

Zhou P, Yang X-L, Wang X-G, Hu B, Zhang L, Zhang W, et al. (2020). A pneumonia outbreak associated with a new coronavirus of probable bat origin. Nature. 579(7798):270-3.

Zhu N, Zhang D, Wang W, Li X, Yang B, Song J, et al. (2020), A Novel Coronavirus from Patients with Pneumonia in China. N Engl J Med;382(8):727-33. 